\title{
Reply to comment by R. Bousquet et al. on "Subduction factory: 1. Theoretical mineralogy, densities, seismic wavespeeds and H2O contents"
}

\author{
Bradley R. Hacker, Geoffrey A. Abers, Simon M. Peacock, and ScottJohnston
}

[1] Steady increases in the mineral physical property database, new methods of calculating the physical properties of rocks, and the growing understanding of ultrahigh-pressure rocks [e.g., Liou et al., 2000] has stimulated considerable effort in recent years to calculate rock phys- ical properties at high to ultrahigh pressure. One approach [e.g., Hacker et al., 2003] is to use the mineral abundances and mineral compositions of natural rocks determined in the field and in experiments. Another approach [e.g., Kerrick and Connolly, 2001] uses the thermodynamic properties ofminerals to calculatemineral abundances and mineral compositions. Both approaches have strengths and weaknesses [Hacker et al., 2003]: the former is grounded in the reality that the mineral abundances and mineral compositions actually exist in natural rocks, the latter has the internal consistency and elegance that comes from a purely theoretical approach. Between these two end-member methodologies lie a range of approaches, including that presented by Bousquet et al. [1997].Hacker et al. [2003] and Bousquet et al. [1997] both used metamorphic facies determined from a combination of natural and experimental studies; the boundaries of the facies fields are relatively similar but differ in key areas where temperatures are low (and thus equilibrium is often not attained) or pressures are unusually high (an area of active research).Hacker et al. [2003] used naturalmineral abundances and compositions to calculate rock physical properties from a mineral equation of state that uses a third-order finite strain approximation with full consider-ation of the effects of changes in pressure and temperature. Bousquet et al. [1997] calculatedmineral abundances from assumed mineral compositions and calculated rock densi-ties at 1 bar and $25^{\circ} \mathrm{C}$ [Goffe'et al., 2003] using an unspecified procedure. Because the thermal expansivities and compressibilities of key minerals such as feldspar translate into density changes of $15 \%$ over the $800^{\circ} \mathrm{C}$ to $3 \mathrm{GPa}$ pressure range of interest [Hacker and Abers, 2004], the differences in these approaches will necessarily lead to different calculated densities.

[2] Our calculated densities do not violate thermody- namics as implied by Bousquet et al. [2005]. With increasing temperature, thermodynamics requires the entropy of a system to increase whereas the density of the system may increase or decrease. With increasing pressure, thermodynamics requires the density of a system to increase, but we and Bousquet et al. [1997, 2005] present calculated densities for the solidminerals, not the whole system which includes $\mathrm{H} 2 \mathrm{O}$ in addition to the solid minerals. The specific example cited, of a temperature-dependent increase in density at $800^{\circ} \mathrm{C}$ and $1.0-1.5 \mathrm{GPa}$, is caused by the dehydration ofamphibole. Our new results "contradict" our previous results [Hacker, 1996] because our new calculations explicitly consider the effect of Fe.

[3] We are perplexed by Bousquet et al.'s [2005] suggestion that our density calculations contradict densities of natural rocks measured by Austrheim [1987]. Austrheim [1987] measured granulite facies anorthositic rocks with densities of 2.79-3.21 g/cm3and mafic eclogites of 3.5-3.6 g/ $\mathrm{cm}^{3}$ but did not specify mineral abundancesor compositions, precluding a direct comparison. If, however, we usemineral compositions from Austrheim and Griffin [1985] and assume mineral abundances typical for granulites (50\% plagioclase, 25\% garnet, and 25\% pyroxene) and eclogites (50\% garnet and 50\% pyroxene), we calculate STPdensities of 3.20 and $3.61 \mathrm{~g} / \mathrm{cm} 3$, in agreement with those measured by Austrheim, who noted that the presence ofmicrocracks and alteration in his rocks would lower the density measurements. It is even more difficult to make comparisons between our calculated densities and the other papers cited by Bousquet et al. [2005]. Green and Ringwood [1967] did not measure the densities of their experimental rocks. Ito and Kennedy [1971] did not measure garnet compositions and reported only a single pyroxene composition. Bousquet et al. [2005] are correct to note that within individual facies fields our calculated densities depend only on the formula weight, molar volume, expansivity $\alpha$, 
$\delta \alpha / \delta \mathrm{T}$, isothermal bulkmodulus $\mathrm{K}_{\mathrm{T}}, \delta \mathrm{K}_{\mathrm{T}} / \delta \mathrm{P}$, shear modulus $\mu, \delta \mathrm{m} / \delta \mathrm{P}, \Gamma=(\delta \ln \mu / \delta \ln \rho) \mathrm{P}$, Grüneisen parameter $\gamma$ th, and the second Gru"neisen parameter $\delta_{\mathrm{T}}=(\delta \ln \mathrm{KT} / \delta \ln \rho)_{\mathrm{P}}$; we do not model the changes in mineral composition and abundance within those individual fields.

[4] It is true that chloritoid occurs in metamafic rocks, particularly in Mg-rich metagabbros of non-mid-ocean ridge basalt (MORB) composition [Droop et al., 1990]. However,we remain unaware of documented occurrences of chloritoid in naturally metamorphosed rocks of MORB composition, the papers cited by Bousquet et al. [2005] notwithstanding. For example,Schliestedt [1986] gives the bulk compositions for nine rocks; one contains chloritoid, and it differs from MORB in having low CaO. As all of Schliestedt's rocks were metamorphosed at the same P-T conditions, the presence of chloritoid in only one requires bulk compositional control; Schliestedt [1986] even notes that chloritoid+omphacite is unstable in these rocks, a prerequi-site for stability of a chloritoid eclogite.Miller[1986]reports no bulk compositions. Bearth [1973] andMessiga et al. [1995] give nobulkcompositions for their chloritoid-bearing rocks, although Messiga et al. [1995] do show that unusually lowCa bulk compositions are required.

[5] It is worth repeating that the (quite valuable) experi-ments of Schmidt and Poli [1998] are unreversed synthesis experiments on glassy starting materials; the presence of a phase in such experiments cannot be taken as proof that such a mineral would exist under equilibrium conditions. The pres-ence of chloritoid in experimental products does not ensure that it is a stable phase. Liu et al. [1996] showed with reversal experiments that chloritoid is metastable in MORB at similar PT conditions.

[6]Bousquet et al. [2005] correctly note that glaucophane and ferro-glaucophane are unstable in MORB at 600800oC and 0.8-1.2 GPa; our choice of these end-members resulted from the fact that the physical properties of rather few amphiboles are well measured. A better choice from a petrological perspective is pargasite, but note that this changes the calculated density by $<0.3 \%$.

[7] Finally, the elegant paper by Kerrick and Connolly [2001] based on Perple_x does indeed show different calculated H2O contents than our Figure 1 because of two main differences: (1) Kerrick and Connolly fixed the maximum $\mathrm{H} 2 \mathrm{O}$ content at $2.5 \mathrm{wt} \%$, whereas we imposed no constraint; and (2) their model rock is an altered MORB that is, for example, enriched in $\mathrm{Al}, \mathrm{Ca}$, and Mg. Their lawsonite stability field, in particular, extends 200oC beyond ours. Using Perple_x for our MORB composition also results in a similar, extended calculated stability field for lawsonite, but we disregard this calculated result because natural rocks that were apparently metamorphosed at these conditions lack lawsonite (our recalculations of the PT results of Feininger [1980], Heinrich [1986], and Okayet al. [1985]).

\section{References}

Austrheim,H. (1987), Eclogitization of lower crustal granulites by fluidmigration throughshear zones, Earth Planet. Sci.Lett., 81, 221-232.

Austrheim,H., and W. L. Griffin (1985), Shear deformation and eclogite formation within granulite-facies anorthosites of the Bergen Arcs, west- ern Norway,Chem. Geol., 50, 267-281.

Bearth, P. (1973), Gesteins- und Mineralparagenesen aus den Ophiolithen von Zermatt. Rock and mineral paragenesis of theophiolites of Zermatt, Switzerland, Schweiz.Mineral. Petrogr.Mitt.,53, 299-334.

Bousquet, R.,B.Goffe,P. Henry, X.Le Pichon, and C. Chopin (1997), Kinematic, thermal and petrological model of the central Alps: Lepontine metamorphism in the upper crust and eclogitisation of the lower crust, Tectonophysics, 273, 105-127. 
Bousquet, R.,B. Goffe',X. Le Pichon, C. de Capitani, C. Chopin, and P. Henry(2005), Comment on "Subduction factory: 1. Theoretical miner- alogy, densities, seismic wave speeds and H2O contents"byBradley Hacker, Geoffrey A. Abers, and Simon M. Peacock, J. Geophys. Res., 110, B02206, doi:10.1029/2004JB003450.

Droop, G. T. R., B. Lombardo, and U. Pognante (1990), Formation and distribution of eclogite facies rocks in the Alps, in Eclogite FaciesRocks, editedbyD. A. Carswell, pp. 225-259, Blackie Acad. and Prof., New York.

Feininger, T. (1980), Eclogite and related high-pressure regional meta- morphic rocks from the Andes of Ecuador, J. Petrol., 21, 107-140. Goffe',B., R. Bousquet, P. Henry, and X. Le Pichon (2003), Effect of the chemical composition of the crust on the metamorphic evolution of oro- genic wedges, J.Metamorph. Geol., 21, $123-141$.

Green, D. H., and A. E. Ringwood (1967), An experimental investigation of the gabbro-eclogite transformation and its petrological implications, Geo- chim. Cosmochim. Acta, 31, 767-833.

Hacker, B. R. (1996), Eclogite formation and the rheology, buoyancy, seismicity, and H2O content of oceanic crust, in Subduction: Topto Bottom, Geophys.Monogr. Ser., vol.96,editedbyG. E. Bebout et al., pp. 337-346, AGU, Washington, D. C.

Hacker,B. R., and G. A. Abers(2004), Subduction Factory 3: An Excel worksheet and macro for calculating the densities, seismic wave speeds, and H2O contents of minerals and rocks at pressure and temperature, Geochem. Geophys. Geosyst., 5, Q01005, doi:10.1029/2003GC000614. Hacker,B. R., G. A. Abers, and S. M. Peacock(2003), Subduction factory: 1. Theoretical mineralogy, density, seismic wave speeds, and H2O content,J. Geophys. Res., 108(B1), 2029, doi:10.1029/2001JB001127.

Heinrich, C. A. (1986), Eclogite facies regional metamorphism ofhydrous mafic rocks in the central alpine Adula Nappe, J. Petrol., 27, 123-154. Ito, K., and G. C. Kennedy(1971), An experimental study of the basalt- garnet granulite-eclogite transition, in The StructureandPhysicalProper- ties of theEarth'sCrust,Geophys.Monogr. Ser., vol. 14, edited by J. G. Heacock, pp. 303-314, AGU, Washington, D. C.

Kerrick, D. M., and J. A. D. Connolly(2001), Metamorphic devolatilization of subducted oceanic metabasalts:Implications for seismicity, arc mag- matism and volatile recycling, Earth Planet. Sci. Lett., $189,19-29$.

Liou, J. G., B. R. Hacker, and R. Y. Zhang (2000), Ultrahigh-pressure (UHP) metamorphism in the forbidden zone,Science, 287, 1215-1216. Liu, J., S. R. Bohlen, and W. G. Ernst (1996), Stability of hydrousphases in subducting oceanic crust,Earth Planet. Sci.Lett., 143, 161-171.

Messiga, B.,M.Scambelluri,and G. B. Piccardo(1995), Chloritoid-bearing assemblages in mafic systems and eclogite-facies hydration of alpine Mg- Al metagabbros(Erro-Tobbio Unit,Ligurian western Alps), Eur. J. Mineral., 7, 1149-1167.

Miller, C. (1986), Alpine high-pressure metamorphism in the eastern Alps, Schweiz.Mineral. Petrogr. Mitt.,66,139-144.

Okay,A. I., M. B. Arman, and M. C. Goncuoglu (1985), Petrology and phase relations of thekyanite-eclogites from eastern Turkey, Contrib. Mineral. Petrol., 91, 196-204.

Schliestedt,M. (1986), Eclogite-blueschist relationships as evidencedby mineral equilibria in the high-pressure metabasic rocks of Sifnos (Cycladic Islands), Greece,J. Petrol., 27, 1437-1459.

Schmidt,M. W., and S. Poli (1998), Experimentally based water budgets for dehydrating slabs and consequences for arc magma generation, Earth Planet. Sci. Lett., 163,361-379. 